\title{
PHYSIOLOGICAL AND SANITARY QUALITY AND OIL CONTENT OF CASTOR BEAN SEEDS UNDER DIFFERENT STORAGE CONDITIONS? ${ }^{1}$
}

\author{
HELOISA OLIVEIRA DOS SANTOS ${ }^{2}$, MARIA LAENE MOREIRA DE CARVALHO ${ }^{2}$, CAMILA APARECIDA \\ LOPES $^{2 *}$, ÉDILA VILELA DE RESENDE VON PINHO ${ }^{2}$, STEFÂNIA VILAS BOAS COELHO ${ }^{2}$
}

\begin{abstract}
The objective of this work was to evaluate the effects of different storage conditions on the physiological and sanitary quality and oil content of castor bean (Ricinus communis) seeds. Seeds of castor bean plants of the Guarani, and IAC-80 cultivars were stored in two environments (cold room, and room conditions), using three package types (multifoliate Kraft paper bag, and polyethylene bag, and polyethylene bag with vacuum at $1 \mathrm{~atm})$. In addition, another storage condition was evaluated: cryopreservation $\left(-196{ }^{\circ} \mathrm{C}\right)$ in foil paper bags. Seed quality was evaluated before storage and at 4, 8, and 12 months after storage by testing their 7 -day and 14-day germination, emergence, health, water content, and oil content. The experiment was conducted in a completely randomized design, with $7 \times 4$ factorial arrangement consisting of seven storage conditions and four evaluation times. Cryopreservation is the ideal condition for maintaining the seed physiological quality of the Ricinus communis cultivars used throughout storage. The oil content of the $R$. communis seeds decreases, and the incidence of Aspergillus spp. and Fusarium spp. fungi increases throughout storage, regardless of the storage conditions.
\end{abstract}

Keywords: Room conditions. Cold room. Cryopreservation. Packaging. Ricinus communis.

\section{A CONDIÇÃO DE ARMAZENAMENTO INTERFERE NO POTENCIAL FISIOLÓGICO E SANITÁRIO E NO TEOR DE ÓLEO DE SEMENTES DE MAMONA?}

\begin{abstract}
RESUMO - Para investigar se diferentes condições de armazenamento interferem no potencial fisiológico, sanitário e no teor de óleo de sementes de mamona (Ricinus communis) foram utilizadas sementes de duas cultivares, Guarani e IAC-80, armazenadas em dois ambientes (câmara fria e armazém convencional) em duas embalagens (saco de papel Kraft multifoliado e saco plástico - com e sem acondicionamento a vácuo a 1 atm). Testou-se ainda outro tipo de acondicionamento, utilizando-se papel aluminizado para criopreservação das sementes $\left(-196^{\circ} \mathrm{C}\right)$. A qualidade das sementes foi avaliada antes do armazenamento e após 4,8 e 12 meses por meio dos testes de geminação (contagem aos 7 e 14 dias), emergência, sanidade, teor de água e teor de óleo. $\mathrm{O}$ delineamento experimental utilizado foi o inteiramente casualizado, em esquema fatorial $7 \mathrm{x} 4$, sendo sete condições de armazenamento e quatro épocas. A criopreservação $\left(-196{ }^{\circ} \mathrm{C}\right)$ é a condição ideal para manutenção do potencial fisiológico de sementes de Ricinus communis, cultivares IAC-80 e Guarani, ao longo do armazenamento. Independente das condições de armazenamento de sementes de R. communis, o teor de óleo decresce e a incidência dos fungos Aspergillus spp. e Fusarium spp. aumenta ao longo do armazenamento.
\end{abstract}

Palavras-chave: Armazém. Câmara fria. Criopreservação. Embalagem. Ricinus communis.

\footnotetext{
${ }^{*}$ Corresponding author

${ }^{1}$ Received for publication in 03/16/2018; accepted in 08/23/2018

Paper extracted from masters dissertation of the first author.

${ }^{2}$ Department of Agriculture, Universidade Federal de Lavras, Lavras, MG, Brazil; heloisa.osantos@ufla.br - ORCID: 0000-0003-13844969, mlaene@gmail.com - ORCID: 0000-0001-9121-3404, camilalopes_sjc@hotmail.com - ORCID: 0000-0002-4913-9607, edila@reitoria.ufla.br-ORCID: 0000-0002-0757-0095, stefaniavbc@gmail.com - ORCID: 0000-0002-6408-9601.
} 


\section{INTRODUCTION}

Castor bean (Ricinus communis L.) is a plant of the Euphorbiaceae family. The oil extracted from its seeds is a promising alternative to produce biodiesel, an ecological biodegradable fuel (MENDES et al., 2009).

Brazil is one of the largest producing countries of $R$. communis (CONAB, 2016); however, the Brazilian average crop yield of this species is low $\left(551 \mathrm{~kg} \mathrm{ha}^{-1}\right)$ compared to other oilseeds, such as soybean, sunflower, and peanuts (FANAN et al., 2009; SANTOS et al., 2016). The use of low-quality seeds that are produced by the farmers themselves (FANAN et al., 2009), and storage problems due to the high oil content of these seeds (35\% to $55 \%$ depending on the cultivar) are factors that contribute to this low yield (SANTOS et al., 2016).

Oil seeds, including $R$. communis, is more affected by storage than starch seeds because lipids have lower chemical stability than starch; a moderate increase in temperature due to the respiratory process is sufficient to increase lipid decomposition and seed deterioration rates (FANAN et al., 2009). Therefore, the storage condition is important for the physiological quality of these seeds; and although it cannot be improved, seeds with good physiological quality are viable for longer periods by delaying the deterioration process (ALMEIDA et al., 2010). Several factors affect the quality of stored seeds, such as seed water content at storage, package use for their conservation, temperature and relative humidity of the storage environment, and seed chemical composition (CALDEIRA et al., 2016). However, few studies on these factors affecting $R$. communis conservation are found (QUEIROGA; BELTRÃO, 2004; FANAN et al., 2009; ALMEIDA et al., 2010; REED et al., 2011; SANTOS et al., 2016).

According to Queiroga and Beltrão (2004), commercial seeds of $R$. communis should be stored with water content of $8 \%$ to $10 \%$ in multilayer paper bags for a maximum of eight months. However, to maintain their quality for a longer period for trade, or conservation of genetic material, other techniques should be used, such as cryopreservation.

Cryopreservation can preserve seeds for unlimited time by reducing their metabolism to low levels, reducing significantly all biochemical processes, and almost stopping deterioration (SANTOS et al., 2016). Traditional conservation methods only postpone deterioration for a specific period, depending on the material and species (COSTA et al., 2012).

In this context, the objective of this work was to evaluate the effects of different storage conditions on the physiological and sanitary quality and oil content of Ricinus communis seeds.

\section{MATERIAL AND METHODS}

The experiment was conducted with Ricinus communis seeds of the Guarani, and IAC-80 cultivars. The seed lot of each cultivar was evaluated by germination tests. The seeds were homogenized, packed in multilayer Kraft paper bags (KPB), polyethylene bags (PEB), and polyethylene bags with vacuum at 0.1 atm $\left(\mathrm{PEB}_{\mathrm{V}}\right)$, and stored in two different environments: room conditions (RC) $\left(25^{\circ}\right.$ $\mathrm{C})$, and cold room (CR) $\left(10^{\circ} \mathrm{C}\right.$ and relative humidity of $50 \%$ ); in addition, they were stored in liquid nitrogen (cryopreservation at $-196{ }^{\circ} \mathrm{C}$ ) in foil paper bags $(\mathrm{CP})$, resulting in seven storage conditions for each cultivar (RC-KPB; RC-PEB, RC-PEB ${ }_{V}, \mathrm{CR}-$ KPB, CR-PEB, CR-PEB ${ }_{\mathrm{V}}$, and CP).

Packed seeds were immersed directly in liquid nitrogen for cryopreservation. The packages containing the seeds were withdrawn from the liquid nitrogen and thawed at room temperature $\left(25 \pm 2{ }^{\circ} \mathrm{C}\right)$ for 24 hours at each evaluation time $(0,4,8$ and 12 months).

The physiological and sanitary quality and oil content of the $R$. communis seeds of each cultivar were evaluated by determining their water content by the oven method at $105 \pm 2{ }^{\circ} \mathrm{C}$ for 24 hours (BRASIL, 2009).

Germination test and first germination count was performed with eight replicates of 25 seeds per treatment, using germination test papers (Germitest $\left.{ }^{\circledR}\right)$, moistened with distilled water at a ratio of $1: 2.5(\mathrm{w} / \mathrm{w})$. The germination test papers with seeds were kept in a germinator with a constant temperature of $25{ }^{\circ} \mathrm{C}$, and germination counts were performed at 7 and 14 days of incubation, with results expressed as percentage of normal seedlings (BRASIL, 2009).

Seedling emergence was evaluated with four replicates of 50 seeds per treatment. The seeds were placed in plastic trays $(60 \times 40 \times 10 \mathrm{~cm})$ containing 4 $\mathrm{kg}$ of a substrate (sand and soil 2:1), with water retention set to $60 \%$. These trays were transferred to a growth chamber at $25^{\circ} \mathrm{C}$. Seedling emergence was evaluated at 21 days after sowing, considering the number of seedlings emerged, with results expressed as percentages.

Emergence speed index was evaluated through daily readings of the number of seedlings with cotyledon leaves above ground (MAGUIRE, 1962).

The oil was extracted from the seeds and its content was determined with three replicates of $25 \mathrm{~g}$ of ground $R$. communis seeds per treatment. The ground material was placed in a volumetric flask $(500 \mathrm{~mL})$ with $200 \mathrm{~mL}$ of the hexane solvent $\left(\mathrm{H}_{3} \mathrm{C}\right.$ $\left.\left(\mathrm{CH}_{2}\right) \mathrm{CH}_{3}\right)$, refluxed for 24 hours, and the solution was then vacuum filtered using a Buchner's funnel. The filtrate was concentrated on a rotary evaporator (Buchi R-114) under reduced pressure. The oil obtained was taken to an oven at $35{ }^{\circ} \mathrm{C}$ for 24 hours 
for complete evaporation of the solvent. The oil content was determined by gravimetric percentageratio between the weights of the oil obtained and seeds subjected to extraction (KOUTROBAS; PAPAKOSTA; DOITSINIS, 2000).

The sanitary test consisted of incubation of seeds in filter paper without freezing (MOURA et al., 2012). The seeds were incubated in Petri dishes (15 $\mathrm{cm}$ in diameter) containing two sheets of filter paper moistened with water plus 2,4dichlorophenoxyacetic acid, using 200 seeds of each treatment divided into eight replicates. The plates were incubated at $20{ }^{\circ} \mathrm{C}$ with photoperiod of 12 hours for seven days, and then evaluated for presence of pathogens.

The experiment was conducted in a completely randomized design, with $7 \times 4$ factorial arrangement consisting of seven storage conditions and four evaluation times. Statistical analysis consisted of analysis of variance, comparison of qualitative data through the Scott-Knott test at 5\% probability, and comparison of quantitative data through regression analysis, using the SISVAR program (FERREIRA, 2011).

\section{RESULTS AND DISCUSSION}

The $R$. communis seeds showed a germination of $80 \%$ (IAC-80) and $75 \%$ (Guarani) before storage, in the initial characterization.

The effect of the storage condition on IAC- 80 seeds varied depending on the evaluation time for four of the five analyzed variables (first germination count, germination percentage, emergency speed index, and emergency percentage). The oil content of these seeds was similar in all storage conditions and evaluation times. The seed germination, and seedling emergence percentages in the different storage conditions were dependent on the evaluation time for Guarani seeds.

The initial water content of seeds packed in paper bags (KPB), polyethylene bags (PEB) polyethylene bags with vacuum $\left(\mathrm{PEB}_{\mathrm{v}}\right)$ and stored at room conditions decreased after four, and eight months of storage (Table 1). These seeds are hygroscopic, their water content vary according to environmental conditions (SILVA et al., 2015). The equilibrium water content is dependent on the chemical composition of the seed. Proteins are the most hygroscopic organic compounds, celluloses and starch the lesser, and lipids are essentially hydrophobic (GOLDFARB; QUEIROGA, 2013). These changes in water content were not found for seeds stored in cold room, and cryopreserved seeds.

Table 1. Water content of Ricinus communis seeds of the IAC- 80 and Guarani cultivars evaluated at $0,4,8$ and 12 months in different storage conditions.

\begin{tabular}{|c|c|c|c|c|c|c|c|c|}
\hline \multirow{2}{*}{ Cultivar } & \multirow{2}{*}{$\begin{array}{c}\text { Evaluation } \\
\text { time }\end{array}$} & \multicolumn{7}{|c|}{ Water contents $(\%)$} \\
\hline & & RC-KPB & RC-PEB & RC-PEB $V$ & CR-KPB & CR-PEB & ${\mathrm{CR}-\mathrm{PEB}_{\mathrm{V}}}$ & $\mathrm{CP}$ \\
\hline \multirow{4}{*}{ IAC-80 } & 0 & 7.8 & 7.7 & 7.7 & 7.8 & 7.6 & 7.8 & 7.4 \\
\hline & 4 & 6.2 & 6.6 & 6.4 & 7.6 & 7.7 & 7.6 & 7.3 \\
\hline & 8 & 5.5 & 5.7 & 5.9 & 7.7 & 7.6 & 7.8 & 7.2 \\
\hline & 12 & 7.3 & 7.1 & 7.1 & 7.8 & 7.5 & 7.6 & 7.5 \\
\hline \multirow{4}{*}{ Guarani } & 0 & 8.0 & 8.1 & 8.0 & 8.2 & 8.1 & 8.0 & 8.2 \\
\hline & 4 & 7.9 & 8.0 & 8.1 & 8.0 & 8.3 & 8.2 & 8.3 \\
\hline & 8 & 7.0 & 7.2 & 7.1 & 8.1 & 8.2 & 8.1 & 8.2 \\
\hline & 12 & 7.8 & 7.7 & 7.9 & 8.3 & 8.3 & 8.0 & 8.1 \\
\hline
\end{tabular}

$\mathrm{KPB}=$ packed in multilayer Kraft paper bags; $\mathrm{PEB}=$ packed in polyethylene bags; $\mathrm{PEB}_{\mathrm{V}}=$ packed in polyethylene bags with vacuum at $0.1 \mathrm{~atm} ; \mathrm{RC}=$ room conditions $\left(25^{\circ} \mathrm{C}\right) ; \mathrm{CR}=$ cold room $\left(10^{\circ} \mathrm{C}\right.$ and relative humidity of $\left.50 \%\right) ; \mathrm{CP}=$ stored in liquid nitrogen (cryopreservation at $-196^{\circ} \mathrm{C}$ ) in foil paper bags.

The percentage of normal seedlings of the IAC-80 cultivar at seven days of germination varied with the storage condition (Table 2). The germination speed of seeds stored in liquid nitrogen was higher than those of seeds stored under other conditions after twelve months of storage. The cryopreservation was beneficial to the preservation of castor bean seeds from the fourth month of storage. According to Kaviani (2011), all biochemical activities decrease during cryopreservation, and biochemical deterioration is interrupted; this preserves the seeds and increases their longevity throughout storage. Almeida et al. (2010) found similar results for five oilseeds, including $R$. communis, denoting the superior physiological quality of seeds stored in liquid nitrogen when compare to conventional environments. 
H. O. SANTOS et al.

Table 2. Percentage of normal seedlings at seven days of germination of Ricinus communis seeds of the IAC-80 cultivar evaluated at $0,4,8$ and 12 months in different storage conditions.

\begin{tabular}{|c|c|c|c|c|c|c|c|c|}
\hline \multirow{2}{*}{ Cultivar } & \multirow{2}{*}{$\begin{array}{c}\text { Evaluation } \\
\text { time }\end{array}$} & \multicolumn{7}{|c|}{ Storage conditions } \\
\hline & & RC-KPB & RC-PEB & RC-PEB ${ }_{V}$ & CR-KPB & CR-PEB & CR-PEB $\mathrm{V}$ & $\mathrm{CP}$ \\
\hline \multirow{4}{*}{ IAC-80 } & 0 & $30.0 \mathrm{Bb}$ & $39.5 \mathrm{Aa}$ & $35.5 \mathrm{Aa}$ & $31.0 \mathrm{Bb}$ & $38.0 \mathrm{Aa}$ & $35.0 \mathrm{Aa}$ & $24.0 \mathrm{Cb}$ \\
\hline & 4 & $39.0 \mathrm{Ab}$ & $31.0 \mathrm{Ac}$ & $25.5 \mathrm{Ac}$ & $41.5 \mathrm{Bb}$ & $27.0 \mathrm{Ac}$ & $40.0 \mathrm{Ab}$ & $57.0 \mathrm{Ba}$ \\
\hline & 8 & $47.5 \mathrm{Ab}$ & $27.0 \mathrm{Ac}$ & $34.0 \mathrm{Ac}$ & $61.5 \mathrm{Aa}$ & $32.5 \mathrm{Ac}$ & $31.5 \mathrm{Ac}$ & $55.0 \mathrm{Ba}$ \\
\hline & 12 & $12.0 \mathrm{Cc}$ & $29.0 \mathrm{Ab}$ & $28.0 \mathrm{Ab}$ & $39.5 \mathrm{Bb}$ & $29.0 \mathrm{Ab}$ & $35.0 \mathrm{Ab}$ & 68.0Aa \\
\hline CV (\%) & \multicolumn{8}{|c|}{19.81} \\
\hline
\end{tabular}

$\mathrm{KPB}=$ packed in multilayer Kraft paper bags; $\mathrm{PEB}=$ packed in polyethylene bags; $\mathrm{PEB}_{\mathrm{V}}=$ packed in polyethylene bags with vacuum at $0.1 \mathrm{~atm} ; \mathrm{RC}=$ room conditions $\left(25^{\circ} \mathrm{C}\right) ; \mathrm{CR}=$ cold room $\left(10^{\circ} \mathrm{C}\right.$ and relative humidity of $\left.50 \%\right)$; $\mathrm{CP}=$ stored in liquid nitrogen (cryopreservation at $-196^{\circ} \mathrm{C}$ ) in foil paper bags. Means followed by the same uppercase letter in the columns and lowercase letter in the rows do not differ by Scott-Knott's test at $5 \%$ probability.

The germination speed of seeds stored in liquid nitrogen, and cold room using paper package increased after four months of storage. The germination speed of seeds packaged in paper bags and stored in cold room increase up to eight months of storage, and up to twelve months for cryopreserved seeds (Figure 1A). Therefore, the cryopreservation of $R$. communis seeds enabled a long-term conservation. Similarly, Santos et al. (2016) evaluated the cryopreservation of $R$. communis seeds of the IAC-226 cultivar and found positive results for this treatment; and Almeida et al. (2010) evaluated cryopreserved seeds of $R$. communis and found a positive effect on the preservation of the quality of these seeds.
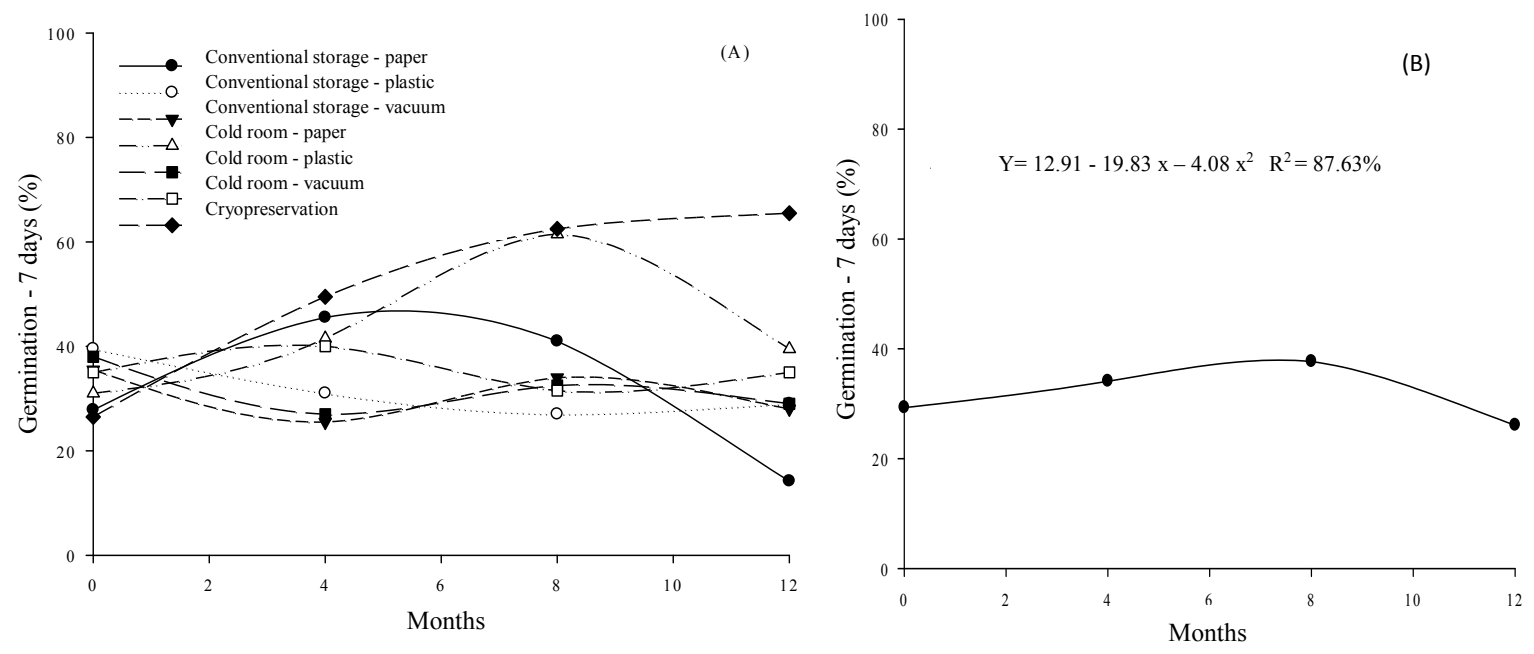

$$
\begin{aligned}
& \text { RC-KPB - (A) } y=-0.6953 x^{2}+7.2062 x-27.825 \quad R^{2}=86.35 \\
& \text { RC-PEB - (A) } y=0.16406 x^{2}-2.85625 x+39.575 \quad R^{2}=99.88^{*} \\
& \text { RCPEB - (A) } y=0.0625 x^{2}-1.1 x+33.85 \quad R^{2}=20.22 \\
& \text { CR-KPB - (A) } y=-0.5078 x^{2}+7.2312 x+28.425 \quad R^{2}=73.49 \\
& \text { CR-PEB - (A) } y=0.1172 x^{2}-1.9437 x+36.725 \quad R^{2}=53.35 \\
& \text { CR-PEB - (A) } y=-0.02344 x^{2}+0.06875 x+36.275 \quad R^{2}=11.38 \\
& \text { CP - (A) v }=-0.3125 x^{2}+7 x+26.5 \quad R^{2}=88.32
\end{aligned}
$$

Figure 1. First germination count of Ricinus communis seeds of the IAC- 80 cultivar evaluated at $0,4,8$ and 12 months in different storage conditions $\left(\mathrm{KPB}=\right.$ packed in multilayer Kraft paper bags; $\mathrm{PEB}=$ packed in polyethylene bags; $\mathrm{PEB}_{\mathrm{V}}=$ packed in polyethylene bags with vacuum at $0.1 \mathrm{~atm} ; \mathrm{RC}=$ room conditions at $25^{\circ} \mathrm{C} ; \mathrm{CR}=$ cold room at $10^{\circ} \mathrm{C}$ and relative humidity of $50 \%$; $\mathrm{CP}=$ stored in liquid nitrogen - cryopreservation at $-196^{\circ} \mathrm{C}$ in foil paper bags) (A); and first germination count of Ricinus communis seeds of the Guarani cultivar evaluated at $0,4,8$ and 12 months of storage.

The first germination count of Guarani seeds showed significant differences within the storage periods (Table 3). The seed germination percentage in the first count increased up to four months and remained constant up to eight months of storage.
Decreases in the number of seedlings in the first germination count was only found at twelve months of storage, but with similar percentages to those found at the beginning of storage (Figure 1B). 
H. O. SANTOS et al.

Table 3. First germination count of Ricinus communis seeds of the Guarani cultivar at $0,4,8$ and 12 months of storage.

\begin{tabular}{cc}
\hline Evaluation time (months) & Normal seedlings (\%) \\
\hline 0 & $29.5 \mathrm{~b}$ \\
4 & $34.0 \mathrm{a}$ \\
8 & $38.0 \mathrm{a}$ \\
12 & $26.0 \mathrm{~b}$ \\
\hline $\mathrm{CV}(\%)$ & 26.8 \\
\hline
\end{tabular}

Means followed by the same letter do not differ by Scott-Knott's test at 5\% probability.

The highest germination percentage was found for IAC- 80 seeds stored in liquid nitrogen, and in cold room (Table 4). However, after eight months of storage, a lower germination percentage was found for seeds packaged in polyethylene bags, or polyethylene bags with vacuum and stored in the cold room, when compared to that of seeds in the other storage conditions. These results were similar at twelve months, with a decrease of up to 47 percentage points in the germination of seeds stored in the cold room when compared to the others. Cryopreservation was efficient in maintaining the physiological quality of IAC- 80 seeds throughout the storage. Even after twelve months of storage, seeds preserved in liquid nitrogen presented germination rates higher than the minimum described by the Brazilian Ministry of Agriculture (Normative Instruction 45 of September 13, 2013) for commercial seeds-80\% germination for $R$. communis seeds (BRASIL, 2013).

The germination percentage of Guarani seeds stored in liquid nitrogen remained constant up to the eighth month of storage, but decreased after this period. The germination percentage of seeds stored in the other conditions decreased after the fourth month. Therefore, the cryopreservation provided better conditions for the conservation of $R$. communis seeds when compared to room, or cold room storage conditions.

Table 4. Normal seedlings in the germination of Ricinus communis seeds of the IAC-80 and Guarani cultivars evaluated at $0,4,8$ and 12 months in different storage conditions.

\begin{tabular}{lcccccccc}
\hline \multirow{2}{*}{ Cultivar } & $\begin{array}{c}\text { Evaluation } \\
\text { time }\end{array}$ & \multicolumn{7}{c}{ Storage conditions } \\
\cline { 2 - 8 } & 0 & $71.0 \mathrm{Ab}$ & $74.5 \mathrm{Ab}$ & $76.5 \mathrm{Ab}$ & $82.0 \mathrm{Aa}$ & $80.0 \mathrm{Aa}$ & $80.0 \mathrm{Aa}$ & $84.0 \mathrm{Aa}$ \\
& 4 & $75.0 \mathrm{Ab}$ & $72.0 \mathrm{Ab}$ & $75.0 \mathrm{Ab}$ & $78.0 \mathrm{Aa}$ & $66.0 \mathrm{Bb}$ & $70.0 \mathrm{Bb}$ & $85.0 \mathrm{Aa}$ \\
$\mathrm{IAC}-80$ & 8 & $78.0 \mathrm{Ab}$ & $66.0 \mathrm{Bb}$ & $72.0 \mathrm{Ab}$ & $73.5 \mathrm{Ab}$ & $57.0 \mathrm{Cc}$ & $63.0 \mathrm{Bc}$ & $85.0 \mathrm{Aa}$ \\
& 12 & $51.5 \mathrm{Bc}$ & $63.5 \mathrm{Bc}$ & $69.5 \mathrm{Ab}$ & $64.5 \mathrm{Bb}$ & $44.0 \mathrm{Dd}$ & $42.0 \mathrm{Cd}$ & $85.0 \mathrm{Aa}$ \\
\hline $\mathrm{CV}(\%)$ & & & 7.53 & & & \\
\hline & 0 & $68.5 \mathrm{Ac}$ & $77.0 \mathrm{Ab}$ & $66.0 \mathrm{Ac}$ & $64.5 \mathrm{Ac}$ & $75.5 \mathrm{Ab}$ & $74.0 \mathrm{Ab}$ & $89.0 \mathrm{Aa}$ \\
Guarani & 4 & $54.0 \mathrm{Bb}$ & $50.0 \mathrm{Bb}$ & $54.0 \mathrm{Bb}$ & $51.5 \mathrm{Bb}$ & $52.0 \mathrm{Bb}$ & $52.5 \mathrm{Bb}$ & $86.0 \mathrm{Aa}$ \\
& 8 & $49.0 \mathrm{Bb}$ & $36.0 \mathrm{Cc}$ & $47.0 \mathrm{Cb}$ & $43.0 \mathrm{Cb}$ & $35.0 \mathrm{Cc}$ & $43.0 \mathrm{Cb}$ & $87.0 \mathrm{Aa}$ \\
& 12 & $27.0 \mathrm{Cc}$ & $31.0 \mathrm{Cc}$ & $39.5 \mathrm{Cb}$ & $36.5 \mathrm{Cb}$ & $29.0 \mathrm{Cc}$ & $23.0 \mathrm{Dc}$ & $66.0 \mathrm{Ba}$ \\
\hline $\mathrm{CV}(\%)$ & & \multicolumn{7}{c}{11.79} \\
\hline
\end{tabular}

Means followed by the same uppercase letter in the columns and lowercase letter in the rows do not differ by Scott-Knott's test at $5 \%$ probability.

The germination percentage of cryopreserved IAC-80 seeds remained constant throughout the storage period (Figure 2A). However, the germination percentage of IAC- 80 seeds stored in the other conditions decreased with storage time. These results denote the effect of the storage condition on the preservation of viability of $R$. communis seeds, as reported by Santos et al. (2016), who evaluated the conservation of $R$. communis seeds in conventional, and cold room conditions for twelve months.

The germination percentage of Guarani seeds decreased from the fourth month, regardless of the storage condition (Figure 2B). Despite this decrease, the highest percentage of normal seedlings were found for cryopreserved seeds when compared to that of seeds stored in the other conditions. The germination percentage of cryopreserved seeds increased at four months of storage when compared to the initial evaluation due to overcoming of dormancy. According to Rocha et al. (2009), cryogenic conservation increases the seed germination percentages and vigor because the low temperature promotes overcoming of dormancy. Despite the efficient of cryopreservation as a method to overcome tegument dormancy, there is no indication in the literature of using subzero temperatures as a method for overcoming dormancy of $R$. communis seeds. 


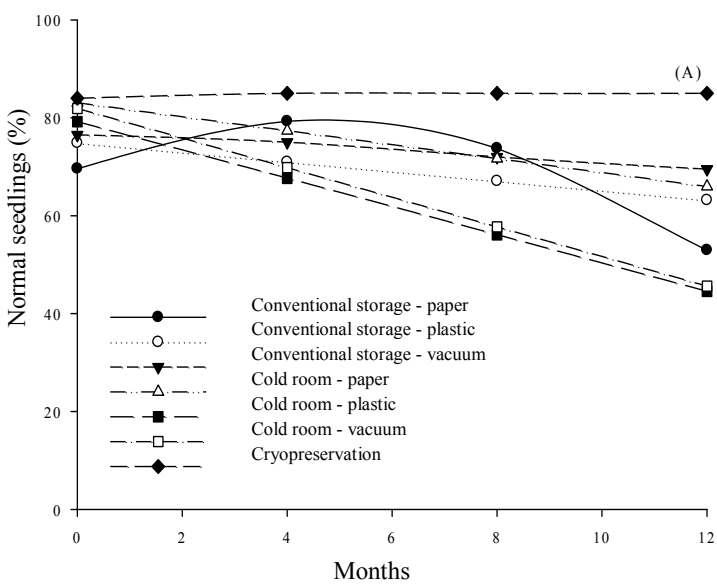

RC-KPB - (A) $y=-0.4766 x^{2}+4.3312 x+69.5750 R^{2}=90.49$ RC-PEB - (A) $y=-0.975 x+74.85 R^{2}=96.88^{*}$ $R C-P E B_{V}-(A) y=-0.6 x+76.85 R^{2}=98.46^{* *}$ $C R-K P B-(A) y=-1.425 x+83.05 \quad R^{2}=95.84^{*}$ CR-PEB - (A) $y=-2.925 x+79.3 R^{2}=99.38^{*}$ CR-PEB - (A) $y=-3.0250 x+81.9 R^{2}=94.25^{*}$ CP - (A) $y=0.075 x+84.3 \quad R^{2}=60$

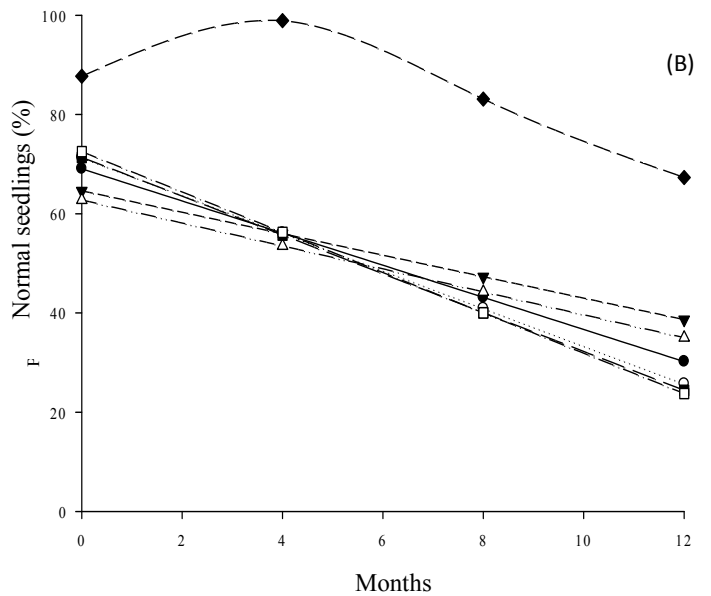

(B) $y=-3.2375 x+69.05 \quad R^{2}=94.46^{*}$ (B) $y=-3.8 x+71.3 \quad R^{2}=90.46$ (B) $y=-2.1625 x+64.6 R^{2}=98.27^{*}$ (B) $y=-2.3125 x+62.75 \quad R^{2}=97.52$ (B) $y=-3.9125 x+71.35 \quad R^{2}=94.04$ (B) $y=-4.0625 x+72.5 \quad R^{2}=98.08^{*}$ (B) $y=-0.2812 x^{2}+1.675 x+87.7 R^{2}=90.23$

Figure 2. Normal seedlings in the germination of Ricinus communis seeds of the IAC-80 (A) and Guarani (B) cultivars evaluated at $0,4,8$ and 12 months in different storage conditions (KPB = packed in multilayer Kraft paper bags; PEB = packed in polyethylene bags; $\mathrm{PEB}_{\mathrm{V}}=$ packed in polyethylene bags with vacuum at $0.1 \mathrm{~atm} ; \mathrm{RC}=$ room conditions at $25^{\circ}$ $\mathrm{C}$; $\mathrm{CR}=$ cold room at $10{ }^{\circ} \mathrm{C}$ and relative humidity of $50 \% ; \mathrm{CP}=$ stored in liquid nitrogen - cryopreservation at $-196{ }^{\circ} \mathrm{C}$ in foil paper bags).

Cryopreservation was more efficient in maintaining the physiological quality of IAC- 80 seeds throughout the storage than the other conditions, confirming the results found in the germination test.

After twelve months of storage, the seeds stored in cold room in polyethylene bags with vacuum resulted in seedlings with lower emergence percentages when compared to those of seeds in the other storage conditions (Table 5). This confirms the action of oxygen restrictions and low temperatures in accelerating the deterioration process of $R$. communis seeds, reducing their longevity (SANTOS et al., 2016).
The storage condition had a significant effect on the seedling emergence of Guarani seeds, with higher percentages for cryopreserved seeds throughout the twelve months of storage, confirming the results found in the germination test. The emergence percentage of cryopreserved seedlings was higher than those of seeds stored in the other conditions, confirming the effect of storage condition on the maintenance of $R$. communis seed quality. The emergence of seedlings from seeds packaged in polyethylene bags, and polyethylene bags with vacuum and stored in cold room was lower than those of seeds stored in the other conditions after twelve months of storage.

Table 5. Emergence of Ricinus communis seedlings of the IAC- 80 and Guarani cultivars evaluated at $0,4,8$ and 12 months in different storage conditions.

\begin{tabular}{|c|c|c|c|c|c|c|c|c|}
\hline \multirow{2}{*}{ Cultivar } & \multirow{2}{*}{$\begin{array}{l}\text { Evaluation } \\
\text { time }\end{array}$} & \multicolumn{7}{|c|}{ Storage conditions } \\
\hline & & RC-KPB & RC-PEB & RC-PEB & CR-KPB & CR-PEB & CR-PEB $\mathrm{V}$ & $\mathrm{CP}$ \\
\hline \multirow{4}{*}{ IAC-80 } & 0 & $69.0 \mathrm{Ac}$ & $74.0 \mathrm{Ab}$ & $65.0 \mathrm{Ac}$ & $67.0 \mathrm{Ac}$ & $60.5 \mathrm{Ad}$ & $67.0 \mathrm{Ac}$ & $92.0 \mathrm{Aa}$ \\
\hline & 4 & $63.0 \mathrm{Bb}$ & $62.0 \mathrm{Bb}$ & $58.5 \mathrm{Bc}$ & $54.0 \mathrm{Bc}$ & $58.5 \mathrm{Ac}$ & $61.0 \mathrm{Bb}$ & $91.0 \mathrm{Aa}$ \\
\hline & 8 & $55.5 \mathrm{Cb}$ & $52.0 \mathrm{Cb}$ & $57.5 \mathrm{Bb}$ & $45.0 \mathrm{Cc}$ & $56.0 \mathrm{Ab}$ & $53.5 \mathrm{Cb}$ & $90.0 \mathrm{Aa}$ \\
\hline & 12 & 49.0Dc & $41.0 \mathrm{Dd}$ & $54.0 \mathrm{Bb}$ & $40.5 \mathrm{Cd}$ & $56.0 \mathrm{Ab}$ & $33.0 \mathrm{De}$ & $85.0 \mathrm{Ba}$ \\
\hline $\mathrm{CV}(\%)$ & \multicolumn{8}{|c|}{6.09} \\
\hline \multirow{4}{*}{ Guarani } & 0 & $49.5 \mathrm{Ab}$ & $40.5 \mathrm{Ac}$ & $41.0 \mathrm{Ac}$ & $45.5 \mathrm{Ab}$ & $45.5 \mathrm{Ab}$ & $41.0 \mathrm{Ac}$ & $86.0 \mathrm{Aa}$ \\
\hline & 4 & $46.5 \mathrm{Ab}$ & $33.5 \mathrm{Bd}$ & $39.5 \mathrm{Ac}$ & $40.5 \mathrm{Ac}$ & $30.0 \mathrm{Bd}$ & $31.0 \mathrm{Bd}$ & $84.0 \mathrm{Aa}$ \\
\hline & 8 & $43.5 \mathrm{Ab}$ & $29.5 \mathrm{Bd}$ & $37.0 \mathrm{Ac}$ & $34.1 \mathrm{Bc}$ & $22.0 \mathrm{Cd}$ & $25.0 \mathrm{Bd}$ & $80.5 \mathrm{Aa}$ \\
\hline & 12 & $28.5 \mathrm{Bb}$ & $29.5 \mathrm{Bb}$ & $34.5 \mathrm{Ab}$ & $23.5 \mathrm{Cc}$ & $17.0 \mathrm{Cd}$ & $11.0 \mathrm{Cd}$ & $67.0 \mathrm{Ba}$ \\
\hline $\mathrm{CV}(\%)$ & \multicolumn{8}{|c|}{10.61} \\
\hline
\end{tabular}

$\mathrm{KPB}=$ packed in multilayer Kraft paper bags; $\mathrm{PEB}=$ packed in polyethylene bags; $\mathrm{PEB}_{\mathrm{V}}=$ packed in polyethylene bags with vacuum at $0.1 \mathrm{~atm} ; \mathrm{RC}=$ room conditions $\left(25^{\circ} \mathrm{C}\right) ; \mathrm{CR}=$ cold room $\left(10{ }^{\circ} \mathrm{C}\right.$ and relative humidity of $50 \%$ ); $\mathrm{CP}=$ stored in liquid nitrogen (cryopreservation at $-196{ }^{\circ} \mathrm{C}$ ) in foil paper bags. Means followed by the same uppercase letter in the columns and lowercase letter in the rows do not differ by Scott-Knott's test at $5 \%$ probability. 
The emergence percentage of seedlings from IAC-80 seeds decreased with storage time. These decreases in emergence of seedlings from seeds stored in liquid nitrogen only occurred from the eighth month of storage, differing from the other treatments (Figure 3A). Seeds packaged in polyethylene bags with vacuum and stored in cold room had the greatest decrease in seedling emergence percentage after twelve months of storage.

The emergence percentage of seedlings from the Guarani seeds decreased, regardless of the seed storage condition from the fourth month of storage, confirming the germination test (Figure 3B). The highest seedling emergence percentage was found for cryopreserved seeds.
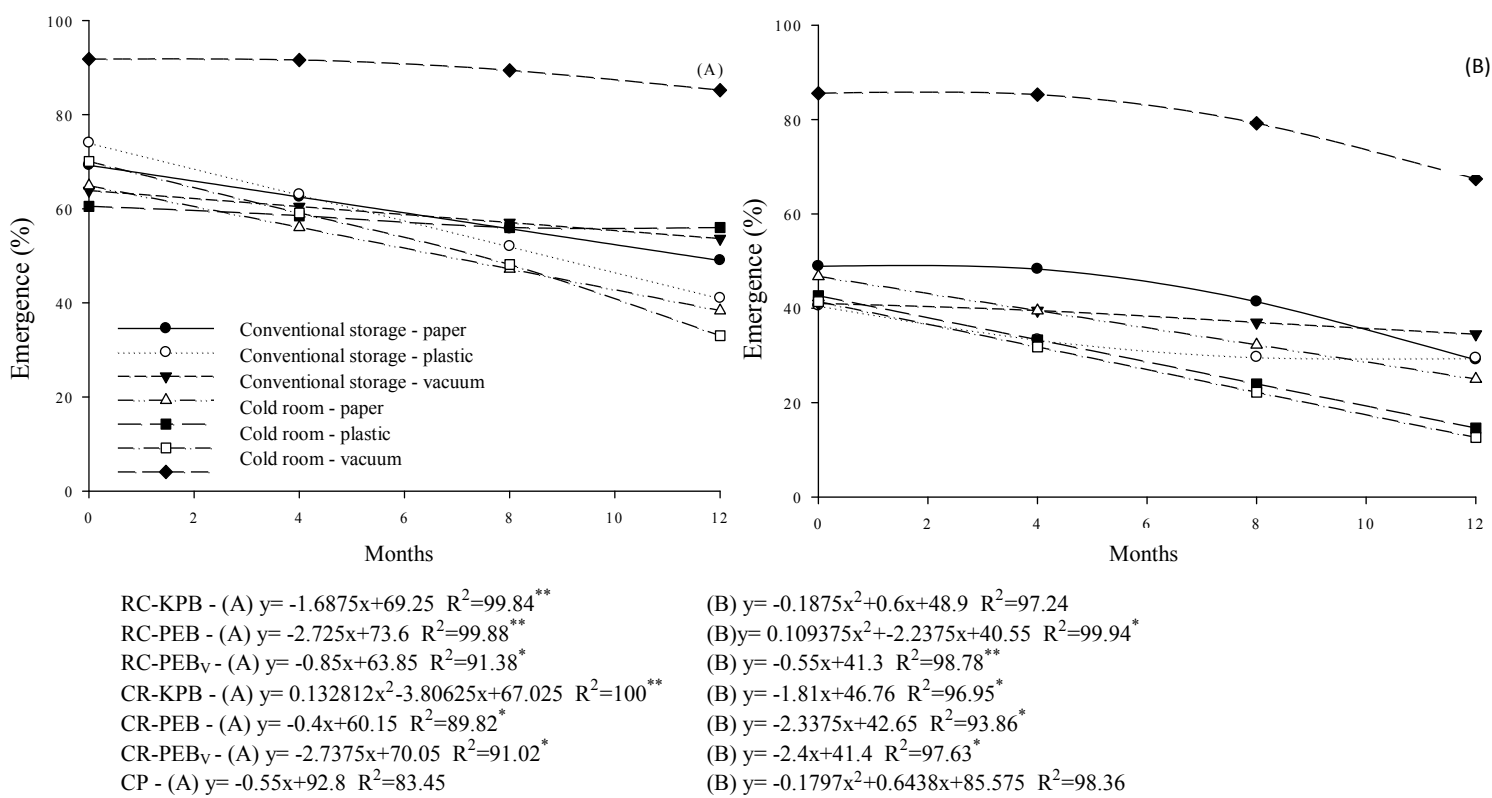

(B) $y=-0.1875 x^{2}+0.6 x+48.9 \quad R^{2}=97.24$

(B) $y=0.109375 x^{2}+-2.2375 x+40.55 \quad R^{2}=99.94^{*}$

(B) $\mathrm{y}=-0.55 \mathrm{x}+41.3 \mathrm{R}^{2}=98.78^{* *}$

(B) $y=-1.81 x+46.76 R^{2}=96.95^{*}$

(B) $y=-2.3375 x+42.65 R^{2}=93.86^{*}$

(B) $y=-2.4 x+41.4 \quad R^{2}=97.63^{*}$

(B) $y=-0.1797 x^{2}+0.6438 x+85.575 R^{2}=98.36$

Figure 3. Emergence of Ricinus communis seedlings of the IAC-80 (A) and Guarani (B) cultivars evaluated at $0,4,8$ and 12 months in different storage conditions $(\mathrm{KPB}=$ packed in multilayer Kraft paper bags; $\mathrm{PEB}=$ packed in polyethylene bags; $\mathrm{PEB}_{\mathrm{V}}=$ packed in polyethylene bags with vacuum at $0.1 \mathrm{~atm} ; \mathrm{RC}=$ room conditions at $25{ }^{\circ} \mathrm{C} ; \mathrm{CR}=$ cold room at $10{ }^{\circ} \mathrm{C}$ and relative humidity of $50 \% ; \mathrm{CP}=$ stored in liquid nitrogen - cryopreservation at $-196{ }^{\circ} \mathrm{C}$ in foil paper bags).

IAC-80 seeds stored in liquid nitrogen presented higher emergency speed than those in the other storage conditions in all evaluations. The seeds stored in cold room in polyethylene bags with vacuum presented the worst performance after twelve months of storage (Table 6).

Table 6. Emergence speed index of Ricinus communis seeds of the IAC-80 cultivar evaluated at 0, 4, 8 and 12 months in different storage conditions.

\begin{tabular}{|c|c|c|c|c|c|c|c|c|}
\hline \multirow{2}{*}{ Cultivar } & \multirow{2}{*}{$\begin{array}{l}\text { Evaluation } \\
\text { time }\end{array}$} & \multicolumn{7}{|c|}{ Storage conditions } \\
\hline & & RC-KPB & RC-PEB & $\mathrm{RC}^{-\mathrm{PEB}_{\mathrm{V}}}$ & CR-KPB & CR-PEB & CR-PEB $\mathrm{V}$ & $\mathrm{CP}$ \\
\hline \multirow{4}{*}{ IAC- 80} & 0 & $2.61 \mathrm{Ac}$ & $2.71 \mathrm{Ac}$ & $3.23 \mathrm{Ab}$ & $2.91 \mathrm{Ac}$ & $3.33 \mathrm{Ab}$ & $2.75 \mathrm{Ac}$ & $4.95 \mathrm{Aa}$ \\
\hline & 4 & 2.44Ad & $2.46 \mathrm{Ad}$ & $2.79 \mathrm{Bc}$ & $2.83 \mathrm{Ac}$ & $3.23 \mathrm{Ab}$ & 2.57Ad & $4.43 \mathrm{Ba}$ \\
\hline & 8 & $2.31 \mathrm{Bc}$ & $2.29 \mathrm{Bc}$ & $2.52 \mathrm{Bc}$ & $2.46 \mathrm{Bc}$ & $3.08 \mathrm{Ab}$ & $2.35 \mathrm{Bc}$ & $4.07 \mathrm{Ca}$ \\
\hline & 12 & $2.09 \mathrm{Bb}$ & $1.95 \mathrm{Cb}$ & $1.92 \mathrm{Cb}$ & $1.90 \mathrm{Cb}$ & $1.82 \mathrm{Bb}$ & $0.96 \mathrm{Cc}$ & $3.11 \mathrm{Da}$ \\
\hline
\end{tabular}

$\mathrm{KPB}=$ packed in multilayer Kraft paper bags; $\mathrm{PEB}=$ packed in polyethylene bags; $\mathrm{PEB}_{\mathrm{V}}=$ packed in polyethylene bags with vacuum at $0.1 \mathrm{~atm} ; \mathrm{RC}=$ room conditions $\left(25^{\circ} \mathrm{C}\right) ; \mathrm{CR}=$ cold room $\left(10^{\circ} \mathrm{C}\right.$ and relative humidity of $\left.50 \%\right)$; $\mathrm{CP}=$ stored in liquid nitrogen (cryopreservation at $-196{ }^{\circ} \mathrm{C}$ ) in foil paper bags. Means followed by the same uppercase letter in the columns and lowercase letter in the rows do not differ by Scott-Knott's test at 5\% probability. 
IAC-80 seeds stored in liquid nitrogen had the highest emergence speed (Figure 4A), but the overall emergence speed decreased with time of storage, even for cryopreserved seeds. These decreases are related to natural deterioration, which is an irreversible process that increases the time needed to obtain an adequate plant stand (ANTONELLO et al.,

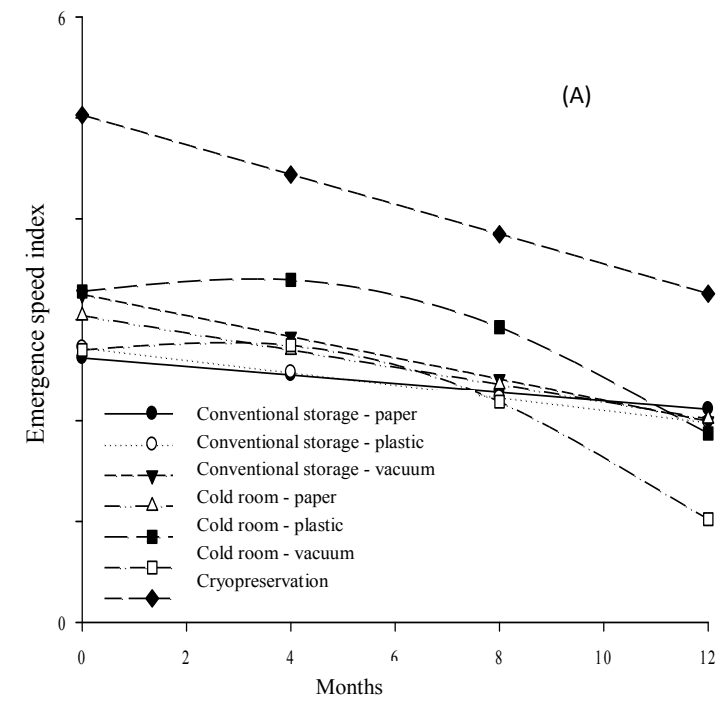

RC-KPB - (A) $y=-0.04225 x-2.616 R^{2}=98.98^{* * *}$

RC-PEB - (A) $y=-0.06125 x+2.72 R^{2}=98.31^{* *}$

$R C-P E B_{V}-(A) y=-0.105 x+3.245 R^{2}=97.9^{*}$

CR-KPB - (A) $y=-0.0075 x^{2}+0.005 x+2.915 \quad R^{2}=99.92^{*}$

CR-PEB - (A) $y=-0.018125 x^{2}+0.1005 x+3.277 \quad R^{2}=96.22$

CR-PEB - - (A) $y=-0.018906 x^{2}+0.087125 x+2.6935 R^{2}=96.8$

$C P-(A) y=-0.147 x+5.022 \quad R^{2}=95.72^{*}$
2009).

The emergence speed index of Guarani seeds did not change due to the storage condition and time of storage, but there were isolated effects of these two variables. The emergence speed of Guarani seeds decreased with increasing storage time (Figure 4B), but it was due to natural deterioration.

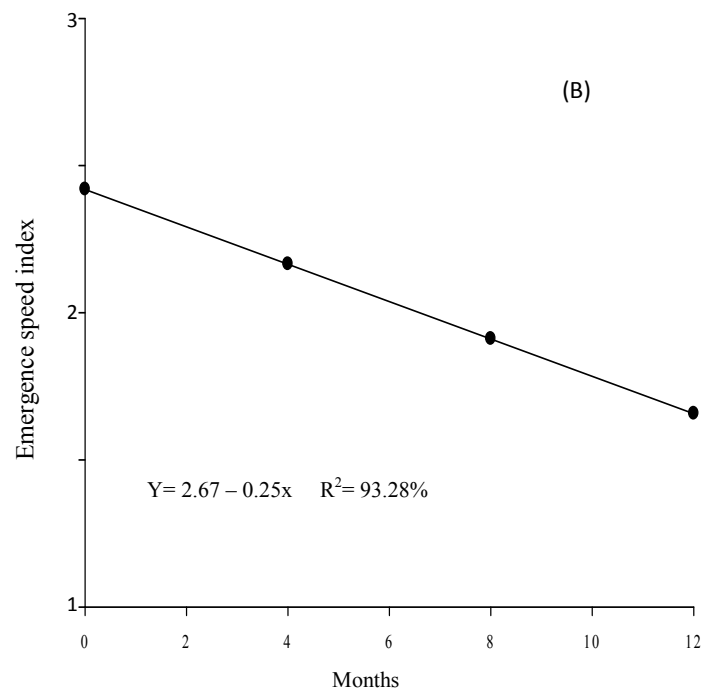

Figure 4. Emergency speed index of Ricinus communis seeds of the IAC-80 cultivar evaluated at 0, 4, 8 and 12 months in different storage conditions (KPB = packed in multilayer Kraft paper bags; $\mathrm{PEB}=$ packed in polyethylene bags; $\mathrm{PEB}_{\mathrm{V}}$ $=$ packed in polyethylene bags with vacuum at $0.1 \mathrm{~atm} ; \mathrm{RC}=$ room conditions at $25^{\circ} \mathrm{C} ; \mathrm{CR}=$ cold room at $10^{\circ} \mathrm{C}$ and relative humidity of $50 \%$; $\mathrm{CP}=$ stored in liquid nitrogen - cryopreservation at $-196{ }^{\circ} \mathrm{C}$ in foil paper bags) (A); and Emergency speed index of Ricinus communis seeds of the Guarani cultivar evaluated at 0, 4, 8 and 12 months of storage.

The emergence speed index of Guarani seeds stored in liquid nitrogen was higher than those of seeds stored in the other conditions (Table 7). According to Antonello et al. (2009), although seed deterioration is an irreversible process, delaying its speed is possible by a correct and efficient management of environmental conditions during storage, which can increase the time that the seeds remain viable during the storage period.

Table 7. Emergence speed index of Ricinus communis seeds of the Guarani cultivar in different storage conditions.

\begin{tabular}{cc}
\hline Storage conditions & Emergence speed index \\
\hline RC-KPB & $1.88 \mathrm{c}$ \\
RC-PEB & $1.63 \mathrm{~d}$ \\
RC-PEB & $2.08 \mathrm{~b}$ \\
CR-KPB & $2.17 \mathrm{~b}$ \\
CR-PEB & $2.07 \mathrm{~b}$ \\
CR-PEB & $1.55 \mathrm{~d}$ \\
CP & $2.85 \mathrm{a}$ \\
\hline CV $(\%)$ & 12.86 \\
\hline
\end{tabular}

$\mathrm{KPB}=$ packed in multilayer Kraft paper bags; $\mathrm{PEB}=$ packed in polyethylene bags; $\mathrm{PEB}_{\mathrm{V}}=$ packed in polyethylene bags with vacuum at $0.1 \mathrm{~atm} ; \mathrm{RC}=$ room conditions at $25^{\circ} \mathrm{C} ; \mathrm{CR}=$ cold room at $10{ }^{\circ} \mathrm{C}$ and relative humidity of $50 \%$; $\mathrm{CP}=$ stored in liquid nitrogen - cryopreservation at $-196{ }^{\circ} \mathrm{C}$ in foil paper bags. Means followed by the same letter do not differ by Scott-Knott's test at $5 \%$ probability. 
The oil content of the IAC-80, and Guarani seeds did not vary with storage times and storage conditions used, these two variables had only isolated effects. The seeds stored in liquid nitrogen presented lower oil content than those in the other storage conditions (Table 8). Since this difference was not dependent on the storage time, it is assumed that the cryopreservation conditions affected the oil extraction or contents in some way. Decreases in oil content of $R$. communis seeds with increasing storage time was found for both cultivars. The oil content of IAC-80 seeds decreased from the fourth month of storage, however, the oil content of Guarani seeds decreased in the first few months of storage (Figure 5). According to Koutrobas, Papakosta and Doitsinis (2000), the storage conditions of castor bean seeds affect significantly their oil content, especially temperature and relative humidity; and variations in the storage conditions cause degradation of the oil.

Table 8. Oil content of Ricinus communis seeds of the IAC-80 and Guarani cultivars in different storage conditions.

\begin{tabular}{ccc}
\hline Cultivar & Storage conditions & Oil content (\%) \\
\hline & RC-KPB & $38.08 \mathrm{~b}$ \\
& RC-PEB & $38.54 \mathrm{~b}$ \\
& RC-PEB & $37.55 \mathrm{~b}$ \\
& CR-KPB & $39.24 \mathrm{~b}$ \\
& CR-PEB & $41.63 \mathrm{a}$ \\
IAC-80 & CR-PEB & $38.23 \mathrm{~b}$ \\
& CP & $31.33 \mathrm{c}$ \\
\hline CV $(\%)$ & & 5.41 \\
\hline & RC-KPB & $39.01 \mathrm{a}$ \\
& RC-PEB & $38.34 \mathrm{a}$ \\
& RC-PEB & $38.64 \mathrm{a}$ \\
Guarani & CR-KPB & $39.10 \mathrm{a}$ \\
& CR-PEB & $38.53 \mathrm{a}$ \\
\hline CV $(\%)$ & CR-PEB & $38.86 \mathrm{a}$ \\
\hline
\end{tabular}

$\mathrm{KPB}=$ packed in multilayer Kraft paper bags; $\mathrm{PEB}=$ packed in polyethylene bags; $\mathrm{PEB}_{\mathrm{V}}=$ packed in polyethylene bags with vacuum at $0.1 \mathrm{~atm} ; \mathrm{RC}=$ room conditions at $25{ }^{\circ} \mathrm{C} ; \mathrm{CR}=$ cold room at $10{ }^{\circ} \mathrm{C}$ and relative humidity of $50 \% ; \mathrm{CP}=$ stored in liquid nitrogen - cryopreservation at $-196{ }^{\circ} \mathrm{C}$ in foil paper bags. Means followed by the same letter do not differ by Scott-Knott's test at $5 \%$ probability.
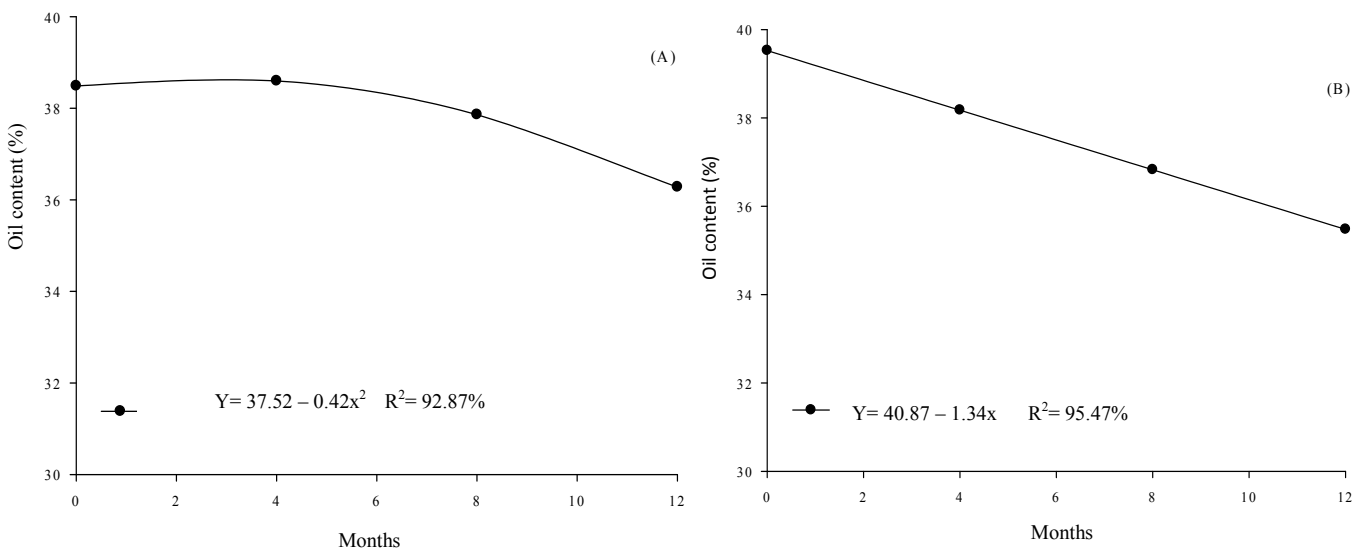

Figure 5. Oil content of Ricinus communis seeds of the IAC-80 (A) and Guarani (B) cultivars evaluated at 0, 4, 8 and 12 months of storage.

Aspergilus spp. and Fusarium spp. were the fungi with the highest occurrence in the sanitary test of IAC- 80 and Guarani seeds, regardless of the storage conditions.

Seeds of the IAC-80 cultivar had higher incidence of Aspergillus flavus (Table 9). A similar result was found by David et al. (2014) in $R$. communis seeds of the IAC-226 cultivar, which had high incidence of this fungus. According to Lima et al. (1997), Aspergillus flavus causes seed rot and affects the germination of castor bean seeds. The occurrence of these microorganisms is associated with the seed storage conditions (DAVID et al., 2014).

Guarani seeds (Table 10) had increases in storage fungi with storage time, and a high incidence of Fusarium oxysporum f. sp. ricini in all seeds, regardless of storage conditions. The high incidence of this fungus in the Guarani seeds is associated with decreases in germination percentage throughout storage. 
H. O. SANTOS et al.

Table 9. Incidence of fungi found in Ricinus communis seeds of the IAC- 80 cultivar evaluated at $0,4,8$ and 12 months in different storage conditions.

\begin{tabular}{|c|c|c|c|c|c|c|c|c|}
\hline \multirow{2}{*}{$\begin{array}{l}\text { Evaluation } \\
\text { time }\end{array}$} & \multirow{2}{*}{ Storage conditions } & \multicolumn{6}{|c|}{ Fungi (\%) } & \multirow[b]{2}{*}{ PH } \\
\hline & & $\mathrm{AF}$ & $\mathrm{AO}$ & AN & $\mathrm{AC}$ & $\mathrm{PE}$ & FU & \\
\hline \multirow{7}{*}{0} & RC-KPB & 42 & 37 & 5 & 0 & 15 & 36 & 0 \\
\hline & RC-PEB & 58 & 38 & 8 & 0 & 13 & 37 & 0 \\
\hline & RC-PEB ${ }_{V}$ & 54 & 38 & 5 & 0 & 14 & 26 & 0 \\
\hline & CR-KPB & 57 & 37 & 4 & 0 & 10 & 36 & 1 \\
\hline & CR-PEB & 56 & 52 & 9 & 0 & 18 & 35 & 0 \\
\hline & CR-PEB ${ }_{V}$ & 58 & 36 & 8 & 0 & 11 & 33 & 0 \\
\hline & $\mathrm{CP}$ & 49 & 10 & 6 & 0 & 14 & 48 & 0 \\
\hline \multirow{7}{*}{4} & RC-KPB & 51 & 41 & 8 & 0 & 17 & 29 & 0 \\
\hline & RC-PEB & 52 & 37 & 10 & 0 & 15 & 31 & 0 \\
\hline & $\mathrm{RC}-\mathrm{PEB}_{\mathrm{V}}$ & 58 & 35 & 9 & 0 & 16 & 34 & 2 \\
\hline & CR-KPB & 61 & 35 & 7 & 0 & 14 & 30 & 0 \\
\hline & CR-PEB & 53 & 39 & 11 & 0 & 18 & 26 & 1 \\
\hline & CR-PEB $V$ & 63 & 41 & 13 & 0 & 19 & 29 & 0 \\
\hline & $\mathrm{CP}$ & 51 & 29 & 12 & 0 & 14 & 35 & 0 \\
\hline \multirow{7}{*}{8} & RC-KPB & 48 & 42 & 20 & 0 & 16 & 31 & 0 \\
\hline & RC-PEB & 53 & 41 & 18 & 0 & 18 & 30 & 0 \\
\hline & RC-PEB $\mathrm{V}$ & 61 & 38 & 18 & 0 & 17 & 24 & 2 \\
\hline & CR-KPB & 62 & 34 & 15 & 0 & 15 & 29 & 0 \\
\hline & CR-PEB & 60 & 37 & 14 & 1 & 14 & 24 & 0 \\
\hline & CR-PEB ${ }_{V}$ & 64 & 45 & 17 & 0 & 19 & 21 & 1 \\
\hline & $\mathrm{CP}$ & 53 & 34 & 17 & 0 & 15 & 32 & 0 \\
\hline \multirow{7}{*}{12} & RC-KPB & 58 & 45 & 22 & 0 & 16 & 26 & 0 \\
\hline & RC-PEB & 62 & 49 & 19 & 1 & 14 & 24 & 0 \\
\hline & RC-PEB ${ }_{V}$ & 61 & 44 & 23 & 3 & 17 & 27 & 0 \\
\hline & CR-KPB & 59 & 42 & 18 & 2 & 18 & 22 & 0 \\
\hline & CR-PEB & 54 & 46 & 16 & 0 & 12 & 20 & 0 \\
\hline & CR-PEB $V$ & 53 & 44 & 17 & 1 & 16 & 23 & 0 \\
\hline & $\mathrm{CP}$ & 52 & 41 & 19 & 2 & 15 & 25 & 0 \\
\hline
\end{tabular}

$\mathrm{KPB}=$ packed in multilayer Kraft paper bags; $\mathrm{PEB}=$ packed in polyethylene bags; $\mathrm{PEB}_{\mathrm{V}}=$ packed in polyethylene bags with vacuum at $0.1 \mathrm{~atm} ; \mathrm{RC}=$ room conditions at $25^{\circ} \mathrm{C} ; \mathrm{CR}=$ cold room at $10{ }^{\circ} \mathrm{C}$ and relative humidity of $50 \% ; \mathrm{CP}=$ stored in liquid nitrogen - cryopreservation at $-196{ }^{\circ} \mathrm{C}$ in foil paper bags. $\mathrm{AF}=$ Aspergillus flavus; $\mathrm{AO}=$ Aspergillus ochraceus; $\mathrm{AN}=$ Aspergillus niger; $\mathrm{AC}=$ Aspergillus candidus $; \mathrm{PE}=$ Penicillium spp.; FU = Fusarium spp; $\mathrm{PH}=$ Phoma spp.

Table 10. Incidence of fungi found in Ricinus communis seeds of the Guarani cultivar evaluated at $0,4,8$ and 12 months in different storage conditions.

\begin{tabular}{|c|c|c|c|c|c|c|c|c|}
\hline \multirow{2}{*}{$\begin{array}{l}\text { Evaluation } \\
\text { time }\end{array}$} & \multirow{2}{*}{ Storage conditions } & \multicolumn{6}{|c|}{ Fungi (\%) } & \multirow[b]{2}{*}{$\mathrm{PH}$} \\
\hline & & $\mathrm{AF}$ & $\mathrm{AO}$ & AN & $\mathrm{AC}$ & $\mathrm{PE}$ & $\mathrm{FU}$ & \\
\hline \multirow{7}{*}{0} & RC-KPB & 36 & 45 & 5 & 0 & 16 & 65 & 0 \\
\hline & RC-PEB & 37 & 49 & 8 & 0 & 18 & 63 & 6 \\
\hline & RC-PEB $\mathrm{V}$ & 26 & 44 & 5 & 0 & 17 & 62 & 0 \\
\hline & CR-KPB & 36 & 42 & 4 & 0 & 15 & 68 & 4 \\
\hline & CR-PEB & 35 & 46 & 9 & 0 & 14 & 65 & 0 \\
\hline & CR-PEB & 33 & 44 & 8 & 0 & 19 & 62 & 3 \\
\hline & $\mathrm{CP}$ & 48 & 41 & 6 & 0 & 15 & 63 & 0 \\
\hline \multirow{7}{*}{4} & RC-KPB & 29 & 43 & 5 & 0 & 20 & 71 & 0 \\
\hline & RC-PEB & 31 & 42 & 8 & 0 & 19 & 74 & 3 \\
\hline & RC-PEB ${ }_{V}$ & 34 & 40 & 5 & 0 & 21 & 73 & 1 \\
\hline & CR-KPB & 30 & 47 & 4 & 1 & 17 & 76 & 0 \\
\hline & CR-PEB & 26 & 46 & 9 & 0 & 18 & 71 & 0 \\
\hline & CR-PEB ${ }_{V}$ & 29 & 45 & 8 & 1 & 20 & 78 & 3 \\
\hline & $\mathrm{CP}$ & 35 & 42 & 6 & 0 & 17 & 72 & 0 \\
\hline \multirow{7}{*}{8} & RC-KPB & 31 & 51 & 11 & 0 & 22 & 78 & 0 \\
\hline & RC-PEB & 30 & 50 & 10 & 7 & 21 & 76 & 0 \\
\hline & RC-PEB ${ }_{V}$ & 24 & 49 & 15 & 3 & 24 & 82 & 5 \\
\hline & CR-KPB & 29 & 47 & 14 & 0 & 27 & 90 & 0 \\
\hline & CR-PEB & 24 & 45 & 11 & 4 & 25 & 83 & 4 \\
\hline & CR-PEB ${ }_{V}$ & 21 & 46 & 9 & 2 & 29 & 75 & 0 \\
\hline & $\mathrm{CP}$ & 32 & 44 & 8 & 0 & 22 & 74 & 0 \\
\hline \multirow{7}{*}{12} & RC-KPB & 26 & 53 & 15 & 0 & 27 & 92 & 0 \\
\hline & RC-PEB & 24 & 50 & 19 & 6 & 28 & 89 & 0 \\
\hline & RC-PEB ${ }_{V}$ & 27 & 58 & 14 & 3 & 31 & 86 & 0 \\
\hline & CR-KPB & 22 & 61 & 16 & 8 & 29 & 91 & 0 \\
\hline & CR-PEB & 20 & 54 & 14 & 0 & 30 & 90 & 0 \\
\hline & CR-PEB $\mathrm{V}$ & 23 & 51 & 12 & 5 & 26 & 85 & 0 \\
\hline & $\mathrm{CP}$ & 25 & 46 & 14 & 3 & 28 & 87 & 0 \\
\hline
\end{tabular}

$\mathrm{KPB}=$ packed in multilayer Kraft paper bags; $\mathrm{PEB}=$ packed in polyethylene bags; $\mathrm{PEB}_{\mathrm{V}}=$ packed in polyethylene bags with vacuum at $0.1 \mathrm{~atm} ; \mathrm{RC}=$ room conditions at $25^{\circ} \mathrm{C} ; \mathrm{CR}=$ cold room at $10{ }^{\circ} \mathrm{C}$ and relative humidity of $50 \%$; $\mathrm{CP}=$ stored in liquid nitrogen - cryopreservation at $196^{\circ} \mathrm{C}$ in foil paper bags. $\mathrm{AF}=$ Aspergillus flavus; $\mathrm{AO}=$ Aspergillus ochraceus; $\mathrm{AN}=$ Aspergillus niger $; \mathrm{AC}=$ Aspergillus candidus $; \mathrm{PE}=$ Penicillium spp.; $\mathrm{FU}=$ Fusarium spp; $\mathrm{PH}=$ Phoma $\mathrm{spp}$.

Rev. Caatinga, Mossoró, v. 32, n. 1, p. 131 - 142, jan. - mar., 2019 


\section{CONCLUSIONS}

The storage conditions affect the physiological quality of $R$. communis seeds of the IAC- 80 and Guarani cultivars. Cryopreservation $\left(-196{ }^{\circ} \mathrm{C}\right)$ is the ideal condition for maintaining the physiological quality of $R$. communis seeds of the IAC-80 cultivar for twelve months, and seeds of the Guarani cultivar for eight months of storage.

The oil content of $R$. communis seeds decreases and the incidence of Aspergillus spp. and Fusarium spp. fungi increases throughout storage, regardless of the seed storage condition.

\section{ACKNOWLEDGEMENTS}

The authors thank the Brazilian Coordination for the Improvement of Higher Education Personnel (Capes) and the Brazilian Council for Scientific and Technological Development (CNPq) for granting scholarships and for the financial support for the development of this research.

\section{REFERENCES}

ALMEIDA, F. A. C. et al. Estudo de técnicas para o armazenamento de cinco oleaginosas em condições ambientas e criogênicas. Revista Brasileira de Produtos Agroindustriais, v. 12, n. 2, p. 189-202, 2010.

ANTONELLO, L. M. et al. Influência do tipo de embalagem na qualidade fisiológica de sementes de milho crioulo. Revista Brasileira de Sementes, v. 31, n. 4, p. 75-86, 2009.

BRASIL. Ministério da Agricultura, Pecuária e Abastecimento. Padrões para produção e comercialização de sementes de mamona (Ricinus communis). Disponível em: < http:// www.agricultura.gov.br/assuntos/insumosagropecuarios/insumosagricolas/sementes-e-mudas/ publicacoes-sementes-e-mudas/

INN45de17desetembrode2013.pdf $>$. Acesso em: 04 out. 2017.

BRASIL. Ministério da Agricultura, Pecuária e Abastecimento. Regras para análise de sementes. Disponível em: <http://www.agricultura.gov.br/ assuntos/insumos-agropecuarios/arquivospublicacoesinsumos/2946_regras_analise_sementes.pdf>. Acesso em: 04 out. 2017.

CALDEIRA, C. M. et al. Qualidade de sementes de tabaco durante o processo de pelotização e armazenamento. Ciência Rural , v. 46, n. 2, p. 216$220,2016$.

COMPANHIA

NACIONAL

DE

ABASTECIMENTO - CONAB. Acompanhamento da safra brasileira de grãos. Disponível em: $<$ http://www.conab.gov.br/OlalaCMS/uploads/ arquivos/16_07_08_17_35_34_Ricinus communis junho2016.pdf $>$ Acesso em: $0 \overline{4}$ out. 2017.

COSTA, L. M. et al. Qualidade de frutos de crambe durante o armazenamento. Revista Brasileira de Sementes, v. 34, n. 2, p. 239-301, 2012.

DAVID, A. M. S. S. et al. Qualidade sanitária de sementes de Ricinus communis (cv. IAC-226). Comunicata Scientiae, v. 5, n. 3, p. 311-317, 2014.

FANAN, S. et al. Influência da colheita e do armazenamento na qualidade fisiológica de sementes de Ricinus communis. Revista Brasileira de Sementes, v. 31, n. 1, p. 150-159. 2009.

FERREIRA, D. F. Sisvar: a computer statistical analysis system. Ciência e Agrotecnologia, v. 35, n. 6, p. 1039-1042, 2011.

GOLDFARB, M.; QUEIROGA, V. P. Considerações sobre o armazenamento de sementes. Revista Tecnologia e Ciência Agropecuária, v. 7, n. 3, p. 71-74, 2013.

KAVIANI, B. Conservation of plant genetic resources by cryopreservation. Australian Journal of Crop Science, v. 5, n. 6, p. 778-800, 2011.

KOUTROUBAS, S. D.; PAPAKOSTA, D. K.; DOITSINIS, A. Water requirements for castor oil crop (Ricinus communis L.) in a Mediterranean climate. Journal of Agronomy and Crop Science, v. 184, n. 1, p. 33-41, 2000.

LIMA, E. F. et al. Fungos causadores de tombamento transportados e transmitidos pela semente da mamoneira. Pesquisa Agropecuária Brasileira, v. 32, n. 1, p. 915-918, 1997.

MAGUIRE, J. D. Speeds of germination aid selection and evaluation for seedling emergence and vigor. Crop Science, v. 2, n. 2, p. 176-177, 1962.

MENDES, R. C. et al. Tratamentos pré-germinativos em sementes de Ricinus communis (Ricinus communis L.). Revista Brasileira de Sementes, v. 31, n. 1, p. 187-194, 2009.

MOURA, J. F. et al. Comparação de métodos de detecção de fungos em sementes de cebola. Pesquisa Agropecuária Pernambucana, v. 17, n. 1, p. 24-29, 2012. 
QUEIROGA, V. P.; BELTRÃO, N. E. M. Produção e armazenamento de sementes de mamona (Ricinus communis L.). 1 ed. Campina Grande: Embrapa, 2004. 7 p. (Comunicado Técnico, 206).

REED, B. et al. Biodiversity conservation and conservation biotechnology tools. In Vitro Cellular \& Developmental Biology, v. 47, n. 1, p. 1- 4, 2011.

ROCHA, M. S. et al. Crioconservação de sementes de algodão. Revista Brasileira de Engenharia Agrícola e Ambiental, v. 13, n. 3, p. 312-318, 2009.

SANTOS, H. O. et al. Physiological and biochemical aspects of castor beans seeds deterioration stored in different packaging conditions and temperatures. Journal of Seed Science, v. 38, n. 3, p. 241-247, 2016.

SILVA, H. W. Higroscopicidade das sementes de pimenta (Capsicum chinese L.). Revista Brasileira de Engenharia Agrícola e Ambiental, v. 19, n. 8, p. 780-784, 2015. 